\title{
Changes and Modifications Occurring in the Category of Japanese Politeness
}

\author{
Patrycja Duc-Harada \\ Jagiellonian University
}

\section{Introduction}

On the ground of Japanese linguistics, the changes that recently occur in various domains of Japanese language are considered as a popular and frequently raised subject. In the discussion on general tendencies noticeable in contemporary use of language it is commonly stated that Nihongo ga kawaru 日本語が変わる "Japanese language changes" and it is usually associated with another commonly discussed problem of the disintegration of Japanese language (Nihongo no midare 日本語の乱れ $)^{2}$. Japanese media frequently spread negative image of innovative processes occurring within Japanese language and often underlines that contemporary Japanese is gradually more and more deprived of its traditional beauty. In order to restore the status of beautiful Japanese (utsukushii Nihongo 美しい日 本語), the great number of books such as Utsukushii Nihongo to tadashii keigo ga mi ni tsuku hon 'How to Master a Beautiful Japanese and Correct Politeness' (2012) are published.

\footnotetext{
${ }^{2}$ H. Kindaichi, "Nihongo wa midarete iru ka?", in: Kawaru Nihongo, Tokyo 1981, pp. 7-62; F. Inoue, Nihongo uotchingu, Tokyo 1988, pp. 195-203.

${ }^{2}$ H. Kindaichi, "Nihongo wa midarete iru ka?", pp. 8-61; F. Inoue, Nihongo uotchingu.
} 
However, predominant part of these linguistic modifications usually has a status of the suggestions for the language change (gengo henka 言語変化) $)^{3}$ which are rarely accepted in the norm of language, and therefore, ought to be regarded as linguistic innovations (gengo inobēshon 言語イノベーション). Moreover, most of these innovations occur in the lexical layer of the language and are usually manifested in informal, colloquial speech represented by youth language (wakamono kotoba 若者言葉) $)^{5}$, mainly on the ground of virtual communication represented by Internet slang (intānetto suranguインターネットスラング).

In contrast to the above-mentioned lexical innovations, which due to their elusiveness and dynamicity do not determine meaningful changes in Japanese language, noticeable transformations occurring in more compound structure of Japanese politeness category (keigo 敬語) influence actual patterns of communication on public or official levels. F. Inoue states that since politeness as a communicative strategy has spread to regular people, all changes occurring in the world influence the use of keigo. ${ }^{6}$

With regard to the status of keigo as a grammatical category of Japanese language, its significance as a respectful speech and complexity based on sophisticated vocabulary and compound benefactive structures, recently observed tendencies to skip overly polite expressions or replace more elaborate Sino-Japanese vocabulary (kango 漢語) with English-based loanwords (gairaigo 外来語) motivate to rethink and reevaluate the current status of keigo.

\section{Aims and Methodology}

The aim of this paper is to analyze noticeable examples of non-standard use of keigo' in recently observed communication behaviors of the Japanese in order to present the most common and relevant modifications occurring in lexical and grammatical layers of Japanese politeness. The analyzes is conducted primarily in

${ }^{3}$ S. Sanada et al., Shakai gengogaku, Tokyo 1992.

${ }^{4}$ S. Yamamoto, Gengo inobēshon toshite no shakuyōgo, Tsukuba Repository 1990, pp. 229-244.

${ }^{5}$ A. Yonekawa, Gendai wakamono kotoba no kō, Tokyo 1996; F. Inoue, Nihongo uotchingu.

${ }^{6}$ F. Inoue, Keigo wa kawaru, Tokyo 2017, p. 13.

' In this paper non-standard use of keigo refers to the examples of untypical and specific use of Japanese words and morphemes that originally were not classified as belonging to the sonkeigo 尊敬語 'honorific speech', kenjōgo 謙譲語 'modest speech' or teineigo 丁 寧語 'polite speech' categories or associated with the patterns of respectful language and behavior. Note that only standard (based on Yamanote dialect of Tokyo) variant of politeness is taken into consideration, while other dialectal variations of language politeness are omitted. 
order to outline the character and range of social and cultural changes occurring in contemporary Japan, which are to certain extent reflected in the structure of Japanese politeness.

There are two meaningful sources for the data introduced and analyzed in this paper. One of them is the analysis of the examples taken from selected scientific papers, dictionaries and textbooks of Japanese honorifics, including manuals and workbooks of business Japanese that were published within the last twenty years. The second source comprises evidences of the actual use of Japanese politeness observed in the selected areas of public space, primarily through the analysis of the real expressions occurring in the speech of the Japanese working in various sorts of public services (transportation, hotels, police boxes, restaurants, convenience stores etc.), as well as written announcements, adverbs and warnings. The examples were collected during short fieldwork conducted in two central regions of Japan (Kantō and Chūbu) in the summer 2018.

During this investigation the following problematic issues that are frequently raised in the discourse on the current status and characteristic of keigo were taken into account:

1. The range and meaning of foreign influences on current polite behaviors, on the example of gairaigo 外来語 'borrowings', wasei eigo 和製英語 'English-based Japanese words' and konseigo 混成語 'hybrids'

2. The most common variants of linguistic errors occurring in the spoken and written honorifics (machigaeta keigo 間違えた敬語 'incorrect politeness') on the example of nijū keigo 二重敬語 'doubled politeness'

3. Politeness in manuals (baito keigoバイト敬語 or manyuaru keigoマニュ アル敬語) as an example of modesty and consideration towards customers expressed in logically and grammatically incorrect polite phrases

4. Democratization of Japanese politeness (keigo no minshuka 敬語の民主 化) as a result of currently observed transformations occurring in Japanese thought, culture and society and the consequence of a communicative strategy of behaving politely (teinei 丁寧) without using polite expressions (teineigo 丁寧 語).

\section{Outcomes of the Analysis}

The recently conducted fieldworks in Japan, supported by the descriptions presented in lexicographic publications, as well as books and papers dedicated to the introduction of actual polite strategies, such as Keigo wa kawaruß, Keigo wa

${ }^{8} \mathrm{~F}$. Inoue, Keigo wa kawaru. 
kowaku nar', Baka ni mieru bijinesu-go ${ }^{10}$, Keigo surasura book ${ }^{11}, K^{2} i g o^{12}$ and Keigo sainyūmon ${ }^{13}$, etc. provided meaningful source of information on the subject of common polite strategies in public communication and revealed noticeable changes observed in the current use and status of keigo. The examples and its short descriptions presented below are provided with the source of origin (reference, situational context or the characteristic of the speaker). With regard to the four problematic issues mentioned in the previous section of this paper, the following tendencies ought to be distinguished and taken into consideration.

1. Japanese language used in public space is to a certain extent influenced by foreign languages. The great number of gairaigo - loanwords from Western languages (mainly English, but also German, Portuguese, Spanish, French or Russian), as well as the tendency to form new expression based on English words or morphemes (wasei eigo) or to mix originally Japanese morphemes with borrowed ones in order to form hybrid expression (konseigo) are considered as common phenomena. Generally speaking, loanwords and other expressions based on borrowed morphemes which are assimilated and then implemented in the language structure are regarded as the outcomes of a common tendency to introduce lexical innovations in order to replace former lexemes or supplement the lack of adequate expressions in particular linguistic context. ${ }^{14}$ The noticeable number of gairaigo is also observed in Japanese business language (bijinesu-go ビジネス語). The most common tendency is to implement loanwords into business language in order to name ideas and objects of the international status, especially in case when there is no necessity to deliberately form lexeme based on Japanese or Sino-Japanese morphemes. The following categories of loanwords can be distinguished: $:^{15}$

\footnotetext{
${ }^{9}$ Idem, Keigo wa kowaku nai. Saishin yōrei to kiso chishiki, Tokyo 1999.

${ }^{10}$ Idem, Baka ni mieru bijinesu-go, Tokyo 2013.

${ }^{11}$ A. Karasawa, Keigo sura sura book, Tokyo 2005.

${ }^{12}$ Y. Kikuchi, Keigo, Tokyo 1994.

${ }^{13}$ Idem, Keigo sainyūmon, Tokyo 2010.

${ }^{14}$ Sanada, Shibuya, Jinnouchi and Sugito $(1992,91)$ in their socio-linguistic reflection on language changes (gengo henka) suggested three types of classification: 1. Due to the structure of the change: internal changes (determined by language development) and external changes (due to foreign language influences); 2 . Due to the range of the change: large-scale (structural, e.g. grammatical) and small-scale (lexical); 3. Due to the social character of the change: sociological (motivated by the influence of social changes) and linguistic (determined by the nature of language) (1992: 91); According to their classifications, loanwords should be generally classified as external, small-scaled and sociological changes.

${ }^{15}$ All introduced examples in this categorization were presented in selected dictionaries of business language, as well as in the book Baka ni mieru bijinesu-go(2013).
} 
a. Gairaigo 外来語- the meaning and form is borrowed from foreign language (usually English) and then assimilated with Japanese phonetics and writing, e.g.:

konsensasu コンセンサス 'consensus', charenji チャレンジ 'challenge', autosōshinguアウトソーシング 'outsourcing', segumento セグメント 'segment', māji マージ 'merge, kuria クリア 'clear', hiaringuヒアリング 'hearing', masuto マスト 'a must', pawā ranchi パワーランチ 'the lunch of business people', jasuto aidea ジャストアイデア 'just idea', shōto nōtisu ショー トノーティス 'at short notice'

Sentence examples:

Shōto nōtisu de kyōshuku desu ga, yoroshiku o-negai itashimasu. ショート ノーティスで恐縮ですが、よろしくお願いいたします。'Excuse me for this urgent matter but I would like to ask for your assistance.'

Sore masuto deshō. それマストでしょう。'This is a must.'

Mondai wa kuria ni naru. 問題はクリアになる。'The matter will become clear.'

b. Gairaigo 外来語 - the meaning of the loanword differs from its English origin and therefore, they are often associated with wasei eigo 和製英語 'English-based Japanese expressions' e.g.:

kurēmu クレーム '(official) complaint' $\leftarrow$ Eng. claim

battinguバティング 'scheduling conflict' $\leftarrow$ Eng. batting

matāマター 'to ask; to entrust' $\leftarrow$ Eng. matter

Sentence example:

Sore wa, Yamada matā desu. それは山田多一です。 'Ask Yamada about it.'

c. Konseigo 混成語 - the combination of English word/ morpheme and originally Japanese word/ morpheme into one Japanese expression, e.g.:

furatto-ka フラット化 'flattening' $\leftarrow$ Eng. flat + Jap. suffix $-k a$ 'process; change'

gurōbaru-ka グローバル化 'globalization' $\leftarrow$ Eng. global + Jap. suffix $-k a$ 'process; change'

kōakusesu好アクセス 'good access' $\leftarrow$ Jap. prefix $k o ̄$ 'good' + Eng. access

d. Shöryaku省略- the contracted form of the borrowing from English, e.g.: risuke リスケ $\leftarrow$ Eng. reschedule, onsuke オンスケ $\leftarrow$ Eng. on schedule, kanibari カニバリ $\leftarrow$ Eng. cannibalization 'reduction in sales volume of one product as a result of the introduction of a new product by the same producer' 
e. Kashira moji 頭文字-acronyms made from English initial letters

$M E C E \leftarrow$ Eng. Mutually Exclusive Collectively Exhaustive

$M \& A \leftarrow$ Eng. mergers and acquisitions

$O K \leftarrow$ Eng. all correct

$A S A P \leftarrow$ Eng. as soon as possible

Sentence examples:

OK de gozaimasu. OK でございます。'It's alright.'

Sono ken, ASAP de o-negai itashimasu. その件、ASAP.でお願いいたします。 'Please, deal with this matter as soon as possible.'

The last two examples of the use of acronyms indicate that borrowed expressions which, additionally originate from colloquial speech or Internet slang, might be also implemented into polite statement - in the first case, by the combination with a humble form of the copula desu $\rightarrow$ de gozaimasu, in the second case, with modest expression for request o-negai itashimasu.

The dictionary of polite language Keigo no o-jiten ${ }^{16}$ offers elaborate descriptions of honorific expressions used in various aspects of Japanese official social life. In this publication, two interesting tendencies based on the use of loanwords can be distinguished. The first one is to implement loanwords into one of the Japanese polite structures (appreciative forms sonkeigo 尊敬語 or humble forms kenjoggo 謙譲語). The second one is to beautify (bika 美化) expression by placing honorific prefix 0 -お in the beginning of the borrowed word.

a. The implementation of loanword in appreciative structure adobaisu nasaruアドバイスなさる 'to kindly give advice' sutoppu nasaru ストップなさる 'to kindlystop' ritaia nasaru リタイアなさる 'to kindly retire'

b. Loanwords as bikago 美化語 'embellished words' o-sōsu おソース 'respected sauce' o-toireおトイレ'respected toilet' o-biru お゙ビール 'respected beer' o-senchiおセンチ 'respectfully sentimental'

The two mentioned processes indicate that foreign vocabulary has a certain impact on Japanese official language, especially business language. However, although the combination of the borrowed word with the indicator of politeness is noticeable in the dictionaries of Japanese language, this strategy is still regarded as relatively innovative and arguable.

${ }^{16} \mathrm{~T}$. Sakamoto and S. Nishikata, Keigo no o-jiten, Tokyo 2009. 
2. The phenomenon of incorrect politeness (machigaeta keigo 間違えた敬語) is a widely discussed issue in recently published papers dedicated to the actual use and status of Japanese language. ${ }^{17}$ The Japanese native speakers are said to unconsciously use and diffuse certain patterns of speech that are morphologically incorrect. The tendency to implement two linguistic indicators of politeness in one structure, called nijū keigo 二重敬語 is regarded as one of the most common mistakes. ${ }^{18}$ Its origin was probably based on the conviction that the more complex the structure is, the more respect it contains. Nowadays, due to its common appearance, incorrect or inappropriate polite forms are hardly distinguished as containing any language errors.

The following examples come from the announcements of the Japanese travel guides of the Japanese tours in Poland.

Osshararemashita仰られました 'he/she kindly said' instead of the correct variant osshaimashita仰いました 'he/she kindly said'. From, the perspective of Japanese politeness, the verb ossharu which is an honorific variant of the verb iu 'to speak', as well as the auxiliary form -rareru are both considered as polite strategies used in order to indicate appreciation towards the listener. The combination of two indicators of keigo in one structure is a common exaggeration and should be regarded as linguistic error. However, the combination of two polite forms in one structure occurs often, and according to Umezu can be determined by the feeling of anxiety of the speaker that in communication on more polite level only one indicator of respect is not sufficient enough. ${ }^{19}$

Go-annai sasete itadakimasu ご案内させていただきます ‘Could you kindly allow me to guide you?' instead of more appropriate variant Go-annai itashimasuご案内いたします'I will humbly guide you'. Although, the motivations for this use are clearly positive and above-mentioned structure is rarely believed as incorrect ${ }^{20}$, the combination of the honorific title go- 御 $/ こ ゙$ with the causative form of the verb suru 'to do' $\rightarrow$ saseru 'let/ allow sb to do' and benefactive auxiliary verb itadaku 'to receive a favor', may offer a misleading

${ }^{17}$ Y. Kitahara, Mondai na Nihongo. Doko ga okashii? Nani ga okashii?, Tokyo 2004; Idem, Mondai na Nihongo. Sono san, Tokyo 2007; A. Karasawa, Keigo surasura book, Tokyo 2005; S. Kobayashi, Sono baito-go o yamenasai, Tokyo 2008.

${ }^{18} \mathrm{M}$. Inoue, Dekiru hito wa, koko made yatte iru: Isshō tsukaeru keigo no kihon ga mi ni tsuku hon, Tokyo 2016, p. 48.

${ }^{19} \mathrm{M}$. Umezu, Shirazu ni tsukatte iru jitsu wa hijosshiki na Nihongo, Tokyo 2013, p. 16.

${ }^{20}$ For instance, although Karasawa in Keigo surasura book suggests the use of Go-annai itashimasu as the most correct choice, in the footnotes he admits that Go-annai sasete itadakimasu is also acceptable (2005, p. 145). 
suggestion that the speaker is deliberately exaggerating. According to Inoue, the tendency to frequently replace modest form itasu with -sasete itadaku transferred to standard language from Kinki dialects. ${ }^{21}$ The use of modest form itasu is said to be more appropriate, though.

Tondemo gozaimasen とんでもございません ‘Don't mention it; you are welcome' instead of the correct variant Tondemonai koto desu とんでもない ことです 'This is a matter you do not have to bother'. Apart from the etymology of this structure, tondemonai is a predicative adjective and structurally synthetic form. However, it is commonly considered as an analytic form (tondemo nal) containing negative form of the verb aru 'to be' $\rightarrow$ nai (in the mentioned case it is combined with a modest variant of negative form nai $\rightarrow$ gozaimasen). ${ }^{22}$ Apparently, the incorrect use seems to be more common than the correct humble variant which is Tondemonai koto de gozaimasu. ${ }^{23}$

3. The employees of Japanese shops, convenience stores (konbinı) and family restaurants (famiresu) are usually obliged to complete special trainings and obtain basic skills of an appropriate behavior and language. Consequently, special manuals and instructions are prepared in order to explain new employees how to respectfully deal with customers and fulfill their requirements. This considerably new kind of Japanese honorifics is usually called baito keigo バイト敬語 'politeness used in part-time job ${ }^{24}$, however, recently due to its quick transfer to other branches of trade, the name manyuaru keigo マニュアル敬語 'politeness from manuals' ${ }^{25}$ seems to be more appropriate. Although, the most important rule is to be maximally polite, the set of special phrases used for the customer's service (sekkyaku furēzu 接客フレーズ) contains grammatical or logical errors.

The examples presented below originate from the frequent statements made by young people working in sales and customer service at Japanese shops and restaurants:

...en o-azukari itashimasu ...円お預かりいたします ‘I will temporarily receive ... yen' instead of more appropriate variant ... en o itadakimasu ...円をい

\footnotetext{
${ }^{21} \mathrm{~F}$. Inoue, Keigo wa kowaku nai. Saishin yōrei to kiso chishiki, Tokyo 1999, p. 160.

${ }^{22}$ Also in one of the workbooks preparing for listening section of the Japanese Language Proficiency Test (JLPT) on the semi-advanced level (N3) Nihongo sōmatome (published in 2010), the incorrect form Tondemo arimasen とんでもありません appears as one of the suggested options.

${ }^{23}$ Y. Kitahara, Mondai na Nihongo. Doko ga okashii? Nani ga okashii?, p. 111.

${ }^{24}$ S. Kobayashi, Sono baito-go o yamenasai, S. Horosawa, "Baito keigo o tsukau wakamonotachi. Hanashite no shinri to kikite no inshō", Bulletin of the Faculty of Regional Studies, 2006.

${ }^{25}$ F. Inoue, Keigo wa kawaru.
} 
ただきます'I will receive ... yen'. Although, the selection of the verb azukaru 'temporarily receive; keep in custody; be entrusted with' in situation when the salesmen is being paid by the customer is a common tendency, it is not adequate. The use of azukaru implicates the transiency and brevity of the action of 'receiving; accepting the money' and consequently, does not accord with a situation of being paid by customer. ${ }^{26}$

Rāmen ni narimasu ラーメンになります 'It will become ramen' instead of the correct variant Rämen de gozaimasu ラーメンでございます'This is (Yours) ramen'. The use of the addressative form of the verb naru 'to become; to result in' in situation when the waiter/waitress is serving a meal, is regarded as inappropriate and illogical. However, this phrase is regarded as indirectly implying that the service of the restaurant did their best to prepare the dish according to the recipe and that they wish to apologize the customer if the meal does not suit his/her refined taste. ${ }^{27}$

O-tsugi no o-kyaku-sama お次のお客様 'The honorably next respected customer' instead of the correct variant Tsugi no o-kyaku-sama次のお客様 'The next respected customer'. The noun tsugi 'next' is one of the most general Japanese counters used to indicate succession. In the mentioned case, the use of honorific titles 0 - is doubled and consequently, the phrase o-tsugi no o-kyaku-sama offers an impression of extreme politeness. Nevertheless, it is morphologically incorrect as the Japanese counters should never be preceded by honorific titles.

Kochira no seki de yoroshikatta deshō kaこちらの席でよろしかったでし ようか'Were you satisfied with this seat?' instead of the correct variant Kochira no seki de yoroshii deshōkaこちらの席でよろしいでしょうか “Are you satisfied with this seat?'. ${ }^{28}$ The use of the past form yoroshikatta of the honorific adjective yoroshii 'good' in situation when the waiter/waitress is asking the customer whether he/she is pleased with the selected seat is often considered as an illogical strategy. However, the selection of the past form is thought to be determined by the pragmatic function of the past tense which in various languages in certain situations is regarded as more polite than pre-

${ }^{26}$ However, in Kobayashi's work the use of azukaru verb is not described as incorrect. The author pays more attention to the use of particle kara 'from' in statements such as ...en kara o-azukari shimasu 1 will receive from ... yen' and suggests to replace it with ...en o-azukari shimasu'I will receive ... yen' (2008: 35-36).

${ }^{27}$ Y. Kitahara, Mondai na Nihongo..., p. 31.

${ }^{28}$ According to Akizuki, in the research conducted in 2005 on the general attitude of the Japanese students towards the phrase yoroshikatta desho $k a, 46.1 \%$ answered that $k i n i$ naru 'it bothers them', 38.5\% responded that ki ni naranai 'it doesn't bother them' and $14.7 \%$ claimed that dochira to mo ienai 'neither agree nor disagree'; see K. Akizuki, Arienai Nihongo, Tokyo 2005, p. 122. 
sent form. ${ }^{29}$ Moreover, according to Kitahara, the selection of the past form may be described as a positive attempt to engage the listener in the act of communication by asking him/her for confirmation of whether the way the speaker was thinking was correct or not. ${ }^{30}$

In the terms of their structure, the phrases for customer service introduced in this section are apparently inappropriate. However, from the pragmatic point of view they fulfill certain function - they offer customers the impression of courtesy and the feeling of consideration (hairyo 配慮) ${ }^{31}$ towards their needs. ${ }^{32}$ The Japanese generally do not sense much of discomfort or incongruity towards manyuaru keigo in their every-day life as they are familiarized with this new kind of polite phrases and regard them as natural feature of public language.

4. The category of Japanese politeness traditionally reflects jōge kankei 上下 関係'hierarchical relations' within Japanese society and, according to Ide, is strongly associated with the feeling of discernment (wakimae 弁え) - the concern and obligation of the individual as a member of a closely knit group within a hierarchical society. ${ }^{33} \mathrm{~F}$. Inoue claims that keigo wa kusuri ni nite iru 'politeness is similar to the medicine ${ }^{34}$, which means that the Japanese use it on different occasions and for different purposes because it is necessary and helpful. They are not very pleased with it, though.

Nevertheless, nowadays certain polite behaviors of the Japanese may be acknowledged as contradictory to the original function and character of keigo. $F$. Inoue notices that in certain communication situations the motivations and expressions of polite behavior seem to slightly drift away from vertical to hori-

${ }^{29}$ Polish example Czy byłby Pan tak uprzejmy? can be translated into English as Would you be so kind... In both cases (Polish bylby and English would be) past variants in conditional forms are used in order to emphasize polite attitude.

${ }^{30}$ Y. Kitahara, Mondai na Nihongo..., pp. 37-38.

${ }^{31}$ Manyuaru keigo examples are often said to express the feeling of consideration (hairyo) towards customers. Generally, the feeling of concern and care is associated with closeness between speaker and listener, which is said to be an attribute of positive polite strategies, and juxtaposed with distance as an attribute of negative strategies [Positive and negative politeness due to Brown and Levinson theory (N. Geyer Discourse and POliteness. Ambivalent Face in Japanese, London 2008, p. 24)]. The appearance of modest forms such as itasu, gozaru, itadaku indicates the presence of negative politeness within manyuaru keigo as well. Consequently, this new kind of keigo epitomizes both positive and negative polite strategies.

${ }^{32}$ F. Inoue, Keigo wa kawaru, p. 20; K. Akizuki, Arienai Nihongo, p. 123.

${ }^{33}$ S. Ide, Wakimae no goyōron, Tokyo 2006.

${ }^{34} \mathrm{~F}$. Inoue, Keigo wa kawaru. 
zontal strategies. ${ }^{35}$ With regard to sociolinguistic research in Okazaki city in Aichi prefecture of Japan, Inoue introduces the term keigo no minshuka 敬語の民主化 'democratization of politeness ${ }^{36}$ claiming that social changes in Japan influence the modification of polite behaviors and its awareness. The term keigo no minshuka is followed by the term keigo no byōdōka 敬語の平等化 'respectful equality' ${ }^{37}$ and reflects the shift in the attitude of language users who prefer to indicate mutual respect based on equality than disparities in statuses. ${ }^{38}$ By means of English or Polish language, it would be said that recently the Japanese prefer to show mutual kindness 'uprzejmośc' than one-directional respect 'szacunek'. It can be also frequently distinguished in public sphere in the language of the Japanese presenters and anchormen that occasionally prefer to use desu/-masu forms than more formalized sonkeigo and kenjogo.

As a result of extra-linguistics factors influencing conversation on formal or semi-formal level, such as the background of the speaker, his/her age, gender and personality, the tendency of being polite (teinei丁寧) without using strictly courteous Japanese forms (teineigo 丁寧語) can be also noticed. For example, recently young Japanese men, especially affiliated with sports clubs (so-called taiikukai-kei 体育会系 'sportsman type; jock') or related to show business, tend to contract addressative forms (desu/-masu forms) to the ending particle -ssu $\supset$ 寸. By adding -ssu to the short form, the message becomes certainly more courteous than by using purely short form, however the level of politeness is noticeably weakened. ${ }^{39}$ Consequently, the image of this kind of polite strategy is rather casual. ${ }^{40}$ The examples presented below originate from the statements of young male presenters frequently appearing in variety shows in Japanese television.

Daijōbu-ssu yo 大丈夫っすよ 'It's alright' instead of Daijōbu desu yo 大丈夫 ですよ

Shitteru-ssu 知ってるっす ‘I know' instead of Shitte imasu 知っています

35 Ibid., p. 20.

${ }^{36}$ Ibid., pp. 16-17.

${ }^{37}$ Ibid., p. 16.

${ }^{38}$ In the author's opinion democratization of keigo should be considered as a delicate matter which requires more careful and elaborate inquiry. Keigo was formerly constructed in order to express the differences in statuses in hierarchical society and consequently, considering it as a linguistic strategy used in order to express mutual equality may be regarded as contradictory to its previous functionality. On the other hand, certain evidences of substituting appreciative and humble forms with status-neutral teineigo clearly indicate the presence of horizontal polite strategies in Japanese official communication.

${ }^{39}$ Ibid., pp. 23-24.

${ }^{40}$ K. Akizuki, Arienai Nihongo, p. 159. 
Sugu kuru-ssu yoすぐ来るっすよ 'I will come soon' instead of Sugu kimasu yo すぐ来ますよ.

The participants of Japanese variety shows were young members of Japanese boy bands, who were asked to interview random Japanese passers-by. When talking to older people they attempted to express polite attitude by adding -ssu to short forms. Although they were considerably teinei 'courteous; polite; kind', they did not use complete teineigo forms as the contracted structures seem more adequate for young and popular men.

However, in certain circumstances the selection of less polite or utterly conversational form is determined by the attributes (zokusei 属性) of the speaker and the impact of social changes seems rather irrelevant. In the following examples, which occurred while being served in Japanese gift shop, convenience store and bar respectively, the tendency to omit sonkeigo and kenjogo in public situations is clearly noticeable.

Issho ni irechatte ii? 一緒に入れちゃっていい? ‘Can I put it together?' instead of Issho demo yoroshii deshōka? 一緒でもよろしいでしょうか 'Would you mind if I put it together?' or O-wake shimasu ka? お分けします か 'Should I put it separately?'

$\mathrm{Ni}$ sen en desu ne 二千円ですね 'Two thousands yen, right?' instead of $N i$ sen en o itadakimasu 二千円をいただきます ‘I humbly receive two thousands yes' (in the meaning of 'Thank you for two thousands yen')

Mō kurōzuもうクローズ 'It's already closed' as a combination of Japanese adverb mō 'already' and English loanword kurōzu 'closed' instead of Sumimasen, heiten desuすみません、閉店です 'I am sorry but we are closed' or Sumimasen ga, mō heiten jikan desuすみませんが、もう閉店時間です‘I am sorry, but we have already closed'.

In the above-mentioned situations some specified extra-linguistic factors determined language behaviors of the speakers. What should be underlined in the first place is that all three statements come from the language of people living in Izu Penisula - a resort area located in the southwest of Tokyo, which is popular for the calm and relaxed atmosphere, beautiful beaches and hot springs. What is more, in first two situations the speakers were elderly people talking to the younger customer. The additional factor that was reflected in the last example was the origin of the listener - the fact that the customer is a young foreigner resulted in the spontaneous use of borrowing. It can be assumed that the colloquial phrase would be substituted with more adequate and courteous expression if, in the similar situation, the listener was a native Japanese person. 
Apparently what determined the particular language behavior in spontaneous communicative situations was not the impact of social changes, but personal selection of the speaker, who, in certain circumstances, can individualize the language by minimizing the impression of formality and offering the listener more familiar expressions.

\section{Conclusion}

This paper provides a brief description of the actual communicative situation in Japan with regard to the potential changes and variations occurring in recent polite strategies. Although keigo is considered as a compound grammatical category that reflects traditional communicative models based on hierarchical relations (jöge kanket) in Japanese society, the present analysis reveals considerably frequent occurrence of innovative strategies of politeness with regard to its lexi$\mathrm{cal}$ and grammatical layers. The influence of Western languages and ideas is reflected in the noticeable number of loanwords which transferred to Japanese business and office language and, as a matter of course, have an impact on Japanese honorifics. On the structural level a common tendency to overuse courtesy (nijü keigo) or use incorrect linguistic patterns in order to increase the impression of modesty and deference in public situations (for instance, in case of manyuaru keigo) is easily identified.

As a consequence of a recent transfer of innovative polite strategies to the public sphere, language purists put a blame on younger generations for having the insufficient knowledge and skills of official Japanese language and consequently, disintegrating Japanese politeness (keigo no konran 敬語の混乱; keigo no midare 敬語の乱机). ${ }^{41}$ Although, the problem of potential disintegration of keigo is a widely discussed topic from the second half of the twentieth century, ${ }^{42}$ the contemporary young Japanese are still discerned as the most responsible group.

Additionally, the changes occurring in Japanese society which are reflected in noticeable transformations of traditional models of work and social and family life result in the decrease of necessity for the use of appreciative and humble forms in every-day situations. Courteous forms (teineigo) or its less formalized, contracted variants $(-s s u)$ are often considered as sufficient in official sphere. These communicative strategies are often linked to a considerably new tendency to replace vertical polite strategies with a kind speech that express mutual consideration (hairyo) between speakers and listeners. The feelings of attention and

${ }^{41}$ F. Inoue, Keigo wa kawaru, p. 16.

${ }^{42}$ Y. Miyaji, "Keigo no konran", in: Gengo seikatsu, Tokyo 1957; H. Kindaichi, "Nihongo wa midarete iru ka?", Kawaru Nihongo, Tokyo 1981. 
care for a positive reception of the polite behavior accord with Lakoffs amenity principle of politeness - be polite means to make a receiver feel good ${ }^{A 3}$ and appear to be more consistent with contemporary society and the actual needs and requirements of its members.

\section{References}

Akizuki, K. (2005). Arienai Nihongo, Tokyo: Chikuma Shinsho.

Bugajski, M. (2006). Język w komunikowaniu, Warszawa: Wydawnictwo Naukowe PWN. Carroll, T. (2013). Language Planning and Language Change in Japan, London: Routledge. Geyer, N. (2008). Discourse and Politeness. Ambivalent Face in Japanese, London: Continuum. Hasegawa, Y. (2012). The Routledge Course in Japanese Translation, London, Routledge. Hasegawa, Y. (2014). Japanese: A Linguistic Introduction, Cambridge: Cambridge University Press.

Horosawa, S. (2006). "Baito keigo o tsukau wakamonotachi. Hanashite no shinri to kikite no inshō", Bulletin of the Faculty of Regional Studies, pp. 1-31.

Huszcza, R. (1996). Honoryfikatywność, Warszawa: Wydawnictwo Akademickie Dialog. Ide, S. (2006). Wakimae no goyōron, Tokyo: Taishūkan Shoten. Inoue, I. (2013). Baka ni mieru bijinesu-go, Tokyo: Seishun Shuppansha.

Inoue, F. (1998). Nihongo uotchingu, Tokyo: Iwanami Shoten.

Inoue, F. (1999). Keigo wa kowaku nai. Saishin yōrei to kiso chishiki, Tokyo: Kōdansha Gendai Shinsho.

Inoue, F. (2017). Keigo wa kawaru, Tokyo: Taishūkan Shoten.

Inoue, M. (2016). Dekiru hito wa, koko made yatteiru: Isshō tsukaeru keigo no kihon ga mi ni tsuku hon, Tokyo: Yamato Shuppan.

Ishiguro, K. (2013). Nihongo wa kūki ga kimeru. Shakai gengogaku nyūmon, Tokyo: Kōbunsha.

Ishiwata, T. (2001). Gairaigo no sōgōteki kenkyū, Tokyo: Tōkyōdō.

Jinnouchi, M. (2007). Gairaigo no shakai gengogaku. Nihongo no gurōkaru na kangaekata, Kyoto: Sekai Shisōsha.

Karasawa, A. (2005). Keigo sura sura book, Tokyo, Seikō Shobō.

Kikuchi, Y. (1994). Keigo, Tokyo: Kōdansha.

Kikuchi, Y. (2010). Keigo sainyūmon, Tokyo: Kōdansha.

Kindaichi H. (1981). "Nihongo wa midarete iru ka?", in: Kindaichi, H., Toyama, Sh., Inagaki, Y., Saiga, H., Haga, Y., Ikeda, Y. Kawaru Nihongo, Kōdansha Zemināru Senshō, Tokyo: Kōdansha, pp. 7-62.

${ }^{43}$ R. Lakoff, "The logic of politeness: Or, minding your p's and q's", Papers from the 9th Regional Meeting of the Chicago Linguistic Society, eds. C. Corum, T. Cedric Smith-Stark and A. Weiser, Chicago 1973, pp. 292-305. 
Kitahara Y. (2004). Mondai na Nihongo. Doko ga okashii? Nani ga okashii? Tokyo: Taishūkan Shoten.

Kitahara, Y. (2007). Mondai na Nihongo. Sono san, Tokyo: Taishūkan Shoten.

Kitahara, Y. (2011). Mondai na Nihongo. Sono yon, Tokyo: Taishūkan Shoten.

Kobayashi, S. (2008). Sono baito-go o yamenasai, Tokyo: Nihon Keizai Shinbun Shuppansha.

Lakoff, R. (1973). "The logic of politeness: Or, minding your p's and q's". Papers from the 9th Regional Meeting of the Chicago Linguistic Society, eds. C. Corum, T. Cedric Smith-Stark, \& A. Weiser, Chicago Linguistic Society, pp. 292-305.

Leech, G. (2014). "The Pragmatics of Politeness", Oxford Studies in Sociolinguistics, Oxford: Oxford University Press.

Marcjanik, M. (2007). Grzeczność w komunikacji językowej, Warszawa: Wydawnictwo Naukowe PWN.

Miyaji, Y. (1957). “Keigo no konran”, in: Gengo seikatsu 70 (1957), Tokyo: Chikuma Shobō, pp. 26-34.

Sakamoto, T. and Nishikata, S. (2009). Keigo no o-jiten, Tokyo: Sanseidō.

Sanada, S., Shibiya, K., Jinnouchi, M. and Sugito, S. (1992). Shakai gengogaku, Tokyo: Ōfū.

Sasaki, H., Matsumoto, N. (2010). Nihongo nōryoku shiken taisaku. Nihongo sōmatome N3, Tokyo: Ask Publishing Co.

Shirazumi, S. (1988). Komyunikēshon to bunka hendō, Tokyo: Hakutō Shobō.

Shō, I. (2011). "Nihongo no shōkosei hyōgen", in: Daigakuin ronbun-shū 8 (2011): 1-14, p. 8.

Takamizawa, H., Hosokawa, T. (1987). Business Japanese: A Guide to Improved Communication, Tokyo: Gloview Co.

Takamizawa, H. (1991). Office Japanese. Ofisu no Nihongo, Tokyo: ALC Press Japanese Textbook Series.

Umezu, M. (2013). Shirazu ni tsukatte iru jitsu wa hijōshiki na Nihongo, Tokyo: Asukomu. Nikkeibipisha (ed.) (2012). Utsukushii Nihongo to tadashii keigo ga mi ni tsukuhon, Houston: Tsai Fong Books.

Yamamoto, S. (1990). Gengo inobēshon toshite no shakuyōgo, in Journal of Japanese Language Teaching 5 (1990), pp. 229-244.

Yonekawa, A. (1996). Gendai wakamono kotoba no kō, Tokyo: Maruzen. 